\title{
Plasminogen activators in experimental colorectal neoplasia: a role in the adenoma-carcinoma sequence?
}

\author{
J S K GELISTER, M R LEWIN, H E DRIVER, F SAVAGE, M MAHMOUD, \\ P J GAFFNEY, AND P B BOULOS
}

From the Department of Surgery, University College London, MRC Toxicology Unit, Carshalton, and National Institute for Biological Standards and Control, London.

SUMMARY An important step in the transition from adenomatous polyp to invasive carcinoma is the degradation of the epithelial basement membrane. By the generation of plasmin, plasminogen activators may play an important role in regulating the extracellular protease activity required for this event to occur. The production of biofunctional urokinase and of tissue plasminogen activator was therefore investigated in the dimethylhydrazine induced rat model of colorectal neoplasia. Both adenomatous polyps ( $p$ values $<0.001$ ) and colorectal carcinomas ( $p$ values $<0.001$ ) were demonstrated to produce a significant excess of both urokinase and tissue plasminogen activator when compared with macroscopically normal colon. There was, however, no increased production of either enzyme by macroscopically normal preneoplastic colon when compared with control colon. This enhanced capacity of colorectal tumours to produce plasminogen activators and generate plasmin is thus a feature of both the premalignant as well as the malignant phenotype. These enzymes may contribute to the malignant potential of adenomatous polyps and to the invasive capacity of established carcinomas.

The concept that the majority of human colorectal carcinomas arise from pre-existing adenomatous polyps, as propounded by Morson' is widely accepted. Well established clinicopathological criteria including polyp size, morphology and degree of dysplasia are recognised as risk factors for the likelihood of malignancy developing in an individual polyp. $^{23}$ The biochemical processes associated with the transition from benign polyp to invasive carcinoma, however, remain ill understood. A critical event in this transition is destruction of the epithelial basement membrane which may be regarded as the first manifestation of invasive behaviour. In malignant neoplasms proteolytic enzyme activity has been widely implicated in both invasion and metastasis, ${ }^{\text {th }}$ however little attention has been focused upon their benign precursors.

Address for correspondence: J S K Gelister, FRCS. Department of Surgery, Faculty of Clinical Science, University College London. The Rayne Institute. 5 University Strect, London WC1E 6JJ.

Received for publication 21 November 1986.
In experimental carcinogenesis an excess production of plasminogen activators in cultured cells has been observed to occur and to precede the morphological features of malignancy. ${ }^{78}$ These serine proteases which exist in two principal forms, as tissue plasminogen activator and urokinase, generate the trypsin like protease plasmin. In a recent study we have confirmed an increase in the concentrations of extractable urokinase from human colorectal carcinomas compared with normal colorectal mucosa and further demonstrated raised levels of this enzyme in adenomatous polyps. ${ }^{9}$

The purpose of this study was to investigate the production of tissue plasminogen activator and urokinase in experimental colorectal neoplasia in rats induced with dimethylhydrazine. Using this model, in which histological evidence exists to support the adenoma-carcinoma sequence," the production of plasminogen activators has been measured in adenomatous polyps and colonic carcinomas. Moreover, as multiple colonic tumours are typical in this model it is conceivable that a generalised epithelial field change associated with an altered capacity to produce plas- 
minogen activators may occur. Therefore the production of these enzymes by macroscopically normal colon from carcinogen treated animals has also been investigated.

\section{Methods}

ANIMALS

Ten outbred female Wistar rats (100-200 g), from groups previously allocated to receive either dimethylhydrazine $(40 \mathrm{mg} / \mathrm{kg}$ sc weekly for five weeks) or to serve as controls, were killed at 20 and 30 weeks and a further 10 control and 15 carcinogen treated animals were killed at 40 weeks. The animals were killed under ether anaesthesia and a full necropsy carried out. In a pilot study plasminogen activator production by colonic explants was found to vary according to the site of sampling, therefore in the present study macroscopically normal colon was always sampled from a fixed site in the future tumour bearing left colon. Weighed explants of colon from both carcinogen treated and control animals and of neoplasms, sampled to give a representative spread of benign and malignant lesions, were thoroughly washed in Hanks balanced salt solution containing penicillin, streptomycin and amphotericin. All tissues were then established in tissue (organ) culture.

\section{TISSUE CULTURE}

The tissue culture media used was Dulbecos modifcation of Eagles medium supplemented with acid treated fetal calf serum containing the same antibiotics as above, glutamine ( $2 \mathrm{mmol})$ and bicarbonate $(500 \mu \mathrm{g} / \mathrm{ml})$. The explants were incubated on iron grids in $4 \mathrm{ml}$ of culture medium in individual wells of tissue culture plates (Gibco) at $37^{\circ} \mathrm{C}$ for 24 hours without $\mathrm{CO}_{2}$ enrichment. The media was then harvested and subaliquots assayed immediately on fibrin plates and further samples snap frozen in liquid nitrogen and stored at $-70^{\circ} \mathrm{C}$ until subsequent analysis as outlined below.

\section{PLASMINOGEN ACTIVATOR ASSAY BY FIBRIN} PLATES

This assay was used as a measure of overall plasminogen activator activity. Plates were all made from the same batch of fibrinogen (Kabi $\mathrm{L}$ grade) using a standardised technique " at a final fibrinogen concentration of $1 \mathrm{mg} / \mathrm{ml}$ in imidazole buffered saline at $\mathrm{pH} 7 \cdot 4$. A sample of fibrinogen which was purified on a lysine sepharose column to remove plasminogen served as a negative control. Sample aliquots of $30 \mu \mathrm{l}$ were assayed in triplicate and lysis areas measured after 21 hours of incubation at $37^{\circ} \mathrm{C}$ and related to a standard tissue plasminogen activator dilution curve.
Results were expressed in tissue plasminogen activator units per $\mathrm{ml}$.

\section{BIOIMMUNOASSAY FOR TISSUE PLASMINOGEN} ACTIVATOR

This assay was used as a measure of biofunctional tissue plasminogen activator-like activity, utilising the established antigenic cross reactivity between rat and human tissue plasminogen activator. ${ }^{2}$ This procedure $^{13}$ depends on the binding of tissue plasminogen activator in the sample to the immobilised IgG fraction of a rabbit antisera raised against human melanoma (Bowes) tissue plasminogen activator. Plasminogen and the chomogenic substrate S2251 (Kabivitrum) were subsequently added such that when present, bound activator converted the plasminogen to plasmin which in turn cleaved pnitroaniline from the chromogenic substrate. The resultant colour change was read as optical density at $405 \mathrm{~nm}$ and the results were read from a dilution curve of the WHO standard of tissue plasminogen activator, being expressed in International Units per $\mathrm{ml}(\mathrm{IU} / \mathrm{ml})$.

\section{UROKINASE ASSAY}

A spectrophotometric assay based on that described by Verheijen ${ }^{14}$ was used as a measure of biofunctional urokinase activity. The assay involves the addition to the plasminogen activator containing sample of a mixture of plasminogen and the chromogenic substrate S2251. Under these conditions there is no contribution to plasmin generation from tissue plasminogen activator, as this enzyme requires the presence of fibrin in order to activate plasminogen (Fig. 1). Standard solutions of both urokinase from

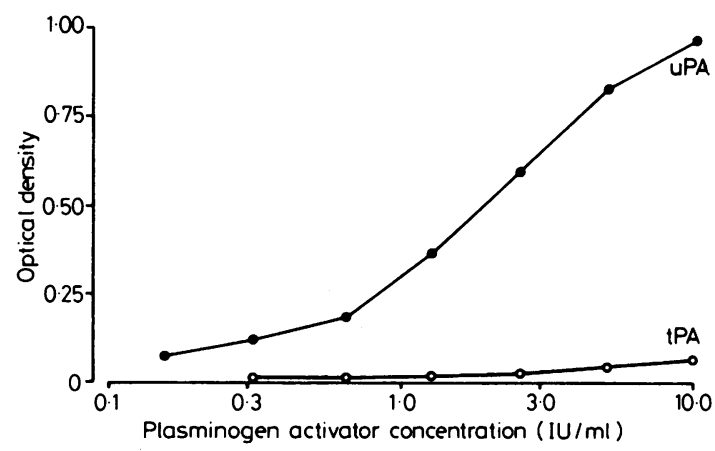

Fig. 1 Spectrophotometric assay for urokinase. The assay was done without the addition of fibrin promoter. Dilution curves of the international standards of both urokinase and tissue plasminogen activator (tPA) as demonstrated above (after incubation for one hour at $37^{\circ} \mathrm{C}$ ) were run within each assay. Under these assay conditions there is a negligible contribution to plasmin generation even at high $(10 \mathrm{IU} / \mathrm{ml})$ tPA concentrations. 
which to calculate the sample results and of tissue plasminogen activator to ensure no contribution from this enzyme were run within each plate. Some samples were additionally incubated without added plasminogen to exclude plasmin independent activity. Results were expressed in International Units of urokinase per $\mathrm{ml}(\mathrm{IU} / \mathrm{ml})$.

\section{HISTOPATHOLOGY}

Portions from each tumour were fixed in formalin, processed and embedded in paraffin wax. Sections $5 \mu \mathrm{m}$ thick were cut and stained with haematoxylin and eosin. Tumours were then histologically classified, independently, as adenoma or carcinoma. In the early part of this study histological interpretation was made of lesions which had been in prolonged tissue culture and some were not classifiable owing to tissue culture artefacts. Subsequently segments of each tumour to be established in tissue culture were placed immediately into formalin. Comparisons between adenomatous polyp and carcinomas have been made only where the histology was unequivocal.

\section{STATISTICAL ANALYSIS}

The data were analysed using the Wilcoxon's ranksum-test for paired and unpaired data where appropriate.

\section{Results}

There were two premature cancer related deaths in the carcinogen treated group and tissue from these animals was not available for study.

\section{CARCINOGEN TREATED VERSUS CONTROL}

NORMAL COLON

The results for plasminogen activator activity in control and macroscopically normal dimethylhydrazine treated colons at 20,30 , and 40 weeks after first exposure to the carcinogen are detailed in Table 1. There were no differences between control and dimethylhydrazine exposed normal colons for overall plasminogen activator activity nor for tissue plasminogen activator or urokinase activity throughout the study. At 30 and 40 weeks, however, dimethylhydrazine treated colons tended to have less tissue plasminogen activator activity and less overall activity. When the data for all the time periods were combined, dimethylhydrazine treated colon tended to have less tissue plasminogen activator and less overall fibrin plate activity, although this was not statistically significant. Urokinase activity did not differ.

\section{NEOPLASM VERSUS MACROSCOPICALLY NORMAL} COLON

In the dimethylhydrazine treated animals a total of 12,25 , and 50 macroscopic tumours respectively at each of the three time periods 20,30 , and 40 weeks were studied. The results for plasminogen activator activities of these tumours compared with their paired macroscopically normal colons are detailed in Table 2. At week 20, the colonic tumours had significantly greater fibrin plate activity $(p<0.001)$ and tissue plasminogen activator activity $(p<0.002)$ than the corresponding dimethylhydrazine colon. The urokinase activity, while higher in the tumours compared with dimethylhydrazine colon just failed to achieve significance. A similar pattern was seen at 30 weeks when the tumours had significantly greater fibrin plate $(p<0.001)$ and tissue plasminogen activator activity $(p<0 \cdot 001)$. Again, urokinase activity, although greater in the tumours than dimethylhydrazine mucosa, did not differ significantly. At 40 weeks all three parameters of plasminogen activator activity in the colonic tumours were significantly greater than those in the corresponding dimethylhydrazine exposed colon ( $p$ values $<0 \cdot 001$ ). When all the data were combined from weeks 20,30 , and 40 , again all the measured parameters of tumour plasminogen activator activity were significantly raised compared with the corresponding dimethylhydrazine ( $p$ values $<0.001)$ as well as the control colon ( $p$ values $<0 \cdot 001)$.

\section{ADENOMATOUS POLYPS VERSUS CARCINOMAS}

An unequivocal histological diagnosis, irrespective of time, was made for 25 adenomatous polyps and for 34 colorectal carcinomas. There were no differences in plasminogen activator activity in any of the assays between the benign and malignant tumours. Both adenomas $(p<0.001)$ and carcinomas $(p<0.001)$ had significantly greater tissue plasminogen activator and

Table 1 Medians and ranges of plasminogen activator levels in control and macroscopically normal DMH exposed rat colons

\begin{tabular}{|c|c|c|c|c|c|c|}
\hline \multirow[b]{2}{*}{ Weeks } & \multicolumn{2}{|c|}{ Fibrin plate $I U / \mathrm{ml}$} & \multicolumn{2}{|l|}{$t P A I U / m l$} & \multicolumn{2}{|c|}{ Urokinase IU/ml } \\
\hline & Control & $D M H$ & Control & $D M H$ & Control & $D M H$ \\
\hline 20 & $0 \cdot 2(0-1 \cdot 6)$ & $0 \cdot 1(0-0 \cdot 6)$ & $0(0-0 \cdot 2)$ & $0(0-0 \cdot 3)$ & $0 \cdot 3(0 \cdot 1-0 \cdot 4)$ & $0.3(0.2-0.4)$ \\
\hline 30 & $0 \cdot 4(0-1 \cdot 0)$ & $0(0-1 \cdot 3)$ & $0.5(0-0 \cdot 9)$ & $0 \cdot 3(0-1 \cdot 1)$ & $0 \cdot 4(0 \cdot 2-1 \cdot 1)$ & $0.4(0 \cdot 1-1.5)$ \\
\hline 40) & $0.9(0-4 \cdot 2)$ & $0 \cdot 5(0-3 \cdot 9)$ & $0 \cdot 2(0-0 \cdot 6)$ & $0 \cdot 1(0-0 \cdot 4)$ & $0 \cdot 3(0-0.5)$ & $0 \cdot 2(0 \cdot 1-0 \cdot 6)$ \\
\hline
\end{tabular}


Table 2 Medians and ranges of plasminogen activator levels of tumours and DMH exposed normal colons

\begin{tabular}{|c|c|c|c|c|c|c|}
\hline \multirow[b]{2}{*}{ Weeks } & \multicolumn{2}{|c|}{ Fibrin plate $\mathrm{IU} / \mathrm{ml}$} & \multicolumn{2}{|l|}{$t P A I U / m l$} & \multicolumn{2}{|c|}{ Urokinase $1 \mathrm{U} / \mathrm{ml}$} \\
\hline & $D M H$ & Tumour & $D M H$ & Tumour & $D M H$ & Tumour \\
\hline 20 & $0 \cdot 1(0-0 \cdot 6)$ & $3 \cdot 2 *(0 \cdot 2-14 \cdot 1)$ & $0(0-0 \cdot 3)$ & $0 \cdot 1 \dagger(0-0 \cdot 6)$ & $0 \cdot 3(0 \cdot 2-0.4)$ & $0.4(0 \cdot 1-1.9)$ \\
\hline 30 & $0(0-1 \cdot 3)$ & $1 \cdot 2 *(0-11 \cdot 4)$ & $0 \cdot 3(0-1 \cdot 1)$ & $1 \cdot 1 *(0 \cdot 3-2 \cdot 8)$ & $0 \cdot 4(0 \cdot 1-1 \cdot 5)$ & $0.6(0 \cdot 1-1 \cdot 7)$ \\
\hline 40 & $0.5(0-3.9)$ & $4 \cdot 2 *(0-70 \cdot 6)$ & $0.1(0-0.4)$ & $0 \cdot 5^{*}(0-1 \cdot 5)$ & $0 \cdot 2(0 \cdot 1-0 \cdot 6)$ & $0 \cdot 4^{*}(0 \cdot 1-10 \cdot 0)$ \\
\hline
\end{tabular}

${ }^{*} \mathrm{p}<0 \cdot 001,+\mathrm{p}<0 \cdot 002$ compared with DMH.

urokinase activity when compared with macroscopically normal colon from either group (Figs. 2,3).

\section{Discussion}

This study has shown that both adenomatous polyps as well as invasive carcinomas are associated with an increased production of both tissue plasminogen activator and urokinase in this model. A tendency to lower tissue plasminogen activator and overall plasminogen activator activity at 30 and 40 weeks in dimethylhydrazine treated colons compared with controls may reflect an inflammatory change in mucosa adjacent to a tumour rather than a true preneoplastic change as with increasing tumour yields the site selected for sampling was frequently close to tumours. We have previously shown that mucosa surrounding human colonic carcinomas had reduced tissue plasminogen activator activity ${ }^{9}$ and a similar observation has been reported in inflammatory bowel disease. ${ }^{15}$

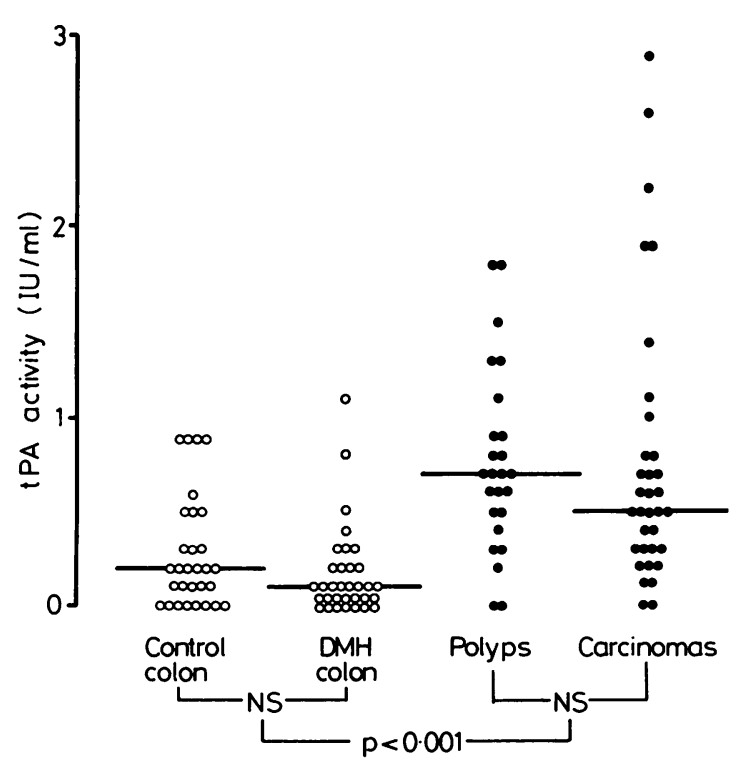

Fig. 2 Tissue plasminogen activator activity in control and dimethylhydrazine (DMH) colon and in histologically confirmed adenomatous polyps and carcinomas.
Whilst it was not possible in this study to show the cellular origin of plasminogen activators it is likely that transformed epithelial cells were the major source of these enzymes in tumours, particularly urokinase. Previous studies have shown the production of this activator by epithelial cells derived from both colorectal carcinomas and adenomatous polyps in cell culture. ${ }^{16}{ }^{17}$ Although infiltrating white cells are a further potential source of protease activity in tumours, lymphocytes have been shown to produce negligible amounts of plasminogen activators unless themselves transformed - for example, by HTLV III, ${ }^{18}$ when appreciable amounts, always including urokinase, were apparent. Moreover, the urokinase content of colonic mucosa from inflammatory bowel disease has been shown not to differ from normal ${ }^{15}$ further supporting the view that abnormalities in the production of this enzyme are a particular feature of transformed cells.

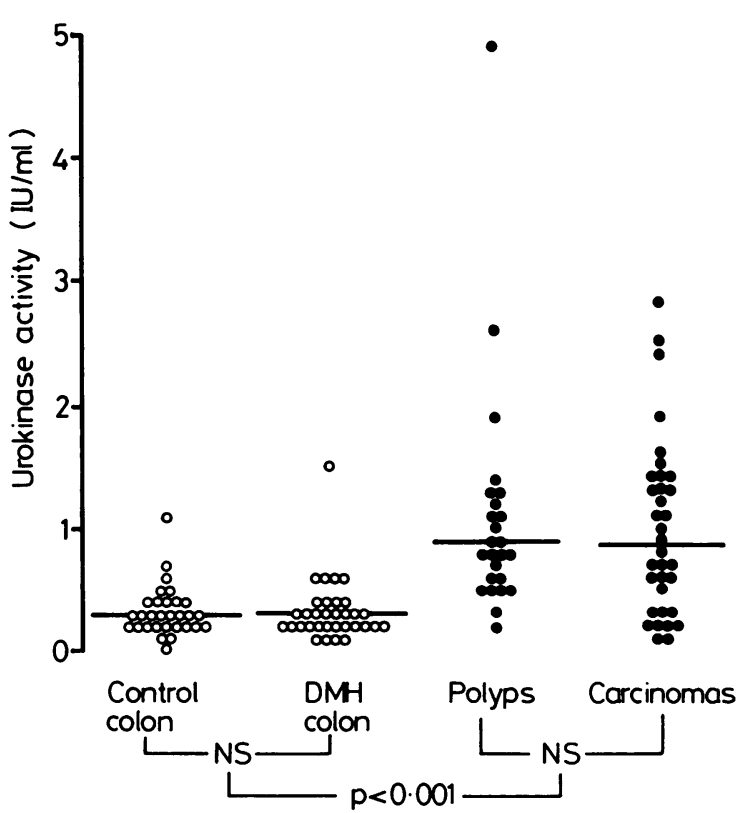

Fig. 3 Urokinase activity in control and dimethylhydrazine (DMH) colon and in histologically confirmed adenomatous polyps and carcinomas. 
Although widely implicated in metastasis there have been few studies of this enzyme system in the tumourigenesis of solid neoplasms. Markus, however, demonstrated a dramatic inhibition of colon tumour development in dimethylhydrazine induced mice fed the fibrinolytic inhibitor epsilon aminocaproic acid and also referred to unpublished observations of increased plasminogen activator synthesis by mouse colon neoplasms in tissue culture. ${ }^{19}$ The present study confirms these latter findings and demonstrates that in this tumour model the enhanced activity is due to an excess production of both tissue plasminogen activator and urokinase. Furthermore, this excessive production of plasminogen activators has been shown to be a feature of both adenomatous polyps as well as carcinomas. Hitherto, reports of abnormalities of plasminogen activator production, which appear almost invariable in cancer, have been confined almost exclusively to either malignant tumours ${ }^{21121}$ or transformed cells ${ }^{\mathrm{x} 21}$ in culture, though not to premalignant tumours.

In a study of extractable plasminogen activator activity in breast neoplasms, ${ }^{22}$ benign breast tumours, unlike breast carcinomas, were found to have virtually undetectable urokinase activity. In human colorectal cancer enhanced urokinase activity has also been observed using both enzyme extraction and organ culture techniques. ${ }^{43}$ Using the former method, raised urokinase was also found in adenomatous polyps although tissue plasminogen activator activity was diminished in both carcinomas and adenomatous polyps when compared with normal colorectal mucosa which contained low but detectable levels of urokinase and comparatively high levels of tissue plasminogen activator. ${ }^{9}$ The discrepancy between the results for tissue plasminogen activator in rat and human colorectal neoplasia may be a reflection of the different methodologies used, namely tissue culture versus enzyme extraction, or may reflect biological differences between rat and human colonic neoplasia. Both studies do, however, show a similar abnormality of plasminogen activator production in adenomatous polyps and colorectal carcinomas. The findings of an increased plasminogen activator production, particularly urokinase, by human villous adenoma and carcinoma derived cells in culture ${ }^{24}$ suggests an aberration of enzyme expression, typical of the malignant phenotype, which occurs at a premalignant stage.

After stimulation with epidermal growth factor (EGF) an increased production of plasminogen activators by various human cells has been observed. ${ }^{5}$ This increased production has been implicated in the down regulation of the EGF receptor. ${ }^{25}$ It is possible therefore that the increased plasminogen activator activity that has often been observed in association with neoplastic tissue may aetiologically be related to deregulated growth control.

The production of urokinase would thus appear to be a particular feature of human and experimental colonic neoplasms. This enzyme, unlike tissue plasminogen activator, can readily generate the trypsin like protease plasmin independently of fibrin. ${ }^{26}$ The degradation of extracellular collagen, as occurs in tumour invasion, is partly mediated by collagenases, enzymes which are often secreted in inactive or latent forms. These enzymes are themselves activated by limited proteolysis and plasmin has been implicated as the enzyme responsible for this activation ${ }^{527}$ as well as for the degradation of laminin and fibronectin, important components of the basement membrane. ${ }^{521}$ The destruction of the basement membrane can be regarded as the first manifestation of invasive behaviour and is a critical event in the transition from adenomatous polyp to invasive carcinoma.

Thus an enhanced production of biofunctional tissue plasminogen activator and urokinase has been observed in both experimental adenomatous polyps and carcinomas in this study. As these enzymes have been widely implicated in tumour invasion this enhanced production may therefore contribute to the malignant potential of adenomatous polyps and to the invasive capacity of carcinomas.

Mr P B Boulos and Mr J S K Gelister gratefully acknowledge support from Smith, Kline \& French Laboratories Ltd, KABI Vitrum, and the Special Trustees of University College Hospital.

\section{References}

1 Morson BC. Precancerous lesions of the colon and rectum. JAMA 1962; 179: 316-21.

2 Muto T, Bussey HJR, Morson BC. The evolution of cancer of the colon and rectum. Cancer 1975; 36: 2251-70.

3 Day DW. The adenoma-carcinoma sequence. Scand J Gastroenterol 1984; 19: suppl 104: 99-107.

4 Goldfarb RH. Proteases in tumour invasion and metastasis. In: Liotta LA, Hart IR, eds. Tumour invasion and metastasis. The Hague: Martinus Nijhoff, 1986.

5 Dano K, Andreassen PA, Grondahl-Hansen J, Kristensen P, Nielsen LS, Skriver L. Plasminogen activators, tissue degradation and cancer. Adv Cancer Res 1985; 44: 138-265.

6 Durdey P, Cooper JC, Switala S, King RFGJ, Williams NS. The role of peptidases in cancer of the rectum and sigmoid colon. Br J Surg 1985; 72: 378-81.

7 Barret JC, Tslo POP. Evidence for the progressive 
nature of transformation in vitro. Proc Natl Acad Sci 1978; 78: 3761-5.

8 Green LJ, Rumsby C, Roscoe J. An increase in plasminogen activator mRNA occurs at an early stage in ethyl-nitrosourea induced transformation of rat brain cells. Carcinogenesis 1986; 7: 477-88.

9 Gelister JSK, Lewin MR, Mahmoud M, Gaffney PJ, Boulos PB. Plasminogen activators in human colorectal neoplasia. Br Med J 1986; 293: 728-31.

10 Madra JL, Harte P, Deasy J, Ross D, Lahey S, Steele G. Evidence for an adenoma-carcinoma sequence in dimethylhydrazine-induced neoplasms of the rat intestinal epithelium. Am J Pathol 1983; 110: 230-5.

11 Marsh NA. In: Fibrinolysis. New York: John Wiley, 1981: 213-4.

12 Kjaelgaard A, Larson B, Astedt B. Immunological comparison between human and rat plasminogen activators in blood and vessel wall. J Clin Pathol 1984; 37: 1153-6.

13 Mahmoud M, Gaffney PJ. Bioimmunoassay of tissue plasminogen activator (tPA) and its specific inhibitor (tPA INH). Thromb Haemostasis 1985; 33: 145-53.

14 Verheijen JH, Mullaert E, Chang GTG, Kluft C, Wingaards G. A simple sensitive spectrophotometric assay for extrinsic (tissue type) plasminogen activator applicable to measurements in plasma. Thromb Haemostasis 1982; 48: 266-9.

15 Verspaget HW, De Bruin PAF, Neterman IT, Verheijen JH, Nap M, Lamers CBHW. Changes in Plasminogen Activator in inflammatory bowel disease (IBD). [Abstract]. Gut 1986; $27:$ A630.

16 Carretero F, Fabra A, Adan, et al. Fibrinolytic activity of human invasive tumours and derived primary cultures. In: Davidson JF, ed. Progress in fibrinolysis. London: Churchill Livingstone, 1985: 267-9.

17 Friedman E, Urmacher C, Winawer S. A Model for human colon carcinoma evolution based on the differential response of cultured pre neoplastic, premalignant and malignant cells to 12-0-tetradecanoyl-phorbol-13acetate. Cancer Res 1.984; 44: 1568-78.

18 Hinuma S, Honda S, Tsukamoto K, Sugamura K, Hinuma $Y$. Production of plasminogen activators by human T-cell leukemia virus transformed cell lines. $\mathrm{BrJ}$ Cancer 1985; 51: 753-9.

19 Corsanti JG, Hobika GH, Markus G. Interference with dimethylhydrazine induction of colon tumours in by epsilon aminocaproic acid. Science 1982; 216: 1020-1.

20 Tissot JD, Hauert J, Bachmann F. Characterisation of plasminogen activators from normal human breast and colon and from breast and colon carcinomas. Int $J$ Cancer 1984; 34: 295-302.

21 Duffy MJ, O'Grady P. Plasminogen Activator and Cancer. Eur J Cancer Clin Oncol 1984; 20: 577-82.

22 O'Grady P, Linjen HR, Duffy MJ. Multiple forms of plasminogen activator in human breast tumours. Cancer Res 1985; 45: 6216-8.

23 Markus G, Camiolo S, Kohga S, Madeja JM, Mittelman A. Plasminogen activator secretion of human tumours in short term organ culture including a comparison of primary and metastatic colon tumours. Cancer Res 1983; 43: $5517-25$.

24 Friedman E, Lipkin M. Proliferation abnormalities in adenomas. Br J Cancer 1986; 54: 138.

25 Gross JL, Krupp MN, Rifkin DB, Lane MD. Downregulation of epidermal growth factor receptor correlates with plasminogen activator activity in human A431 epidermoid carcinoma cells. Proc Natl Acad Sci 1983; 80: $2276-80$.

26 Matsuo O, Rifken DC, Collen D. Comparison of the relative fibrinolytic and thrombolytic activities of tissue plasminogen activator and urokinase in vitro. Thromb Haemostasis 1981; 45: 225-9.

27 O'Grady RL, Upfold LI, Stephens RW. Rat mammary carcinoma cells secrete active collagenase and activate latent collagenase in the stroma via plasminogen activator. Int J Cancer 1981; 28: 509-15. 